\title{
Effect of Seed pre treatment on Seed Germination and Seedling Growth of Papaya
}

\author{
Gangaram Rana*, Prahlad Deb, Buddhisatya Dowarah and Kanne Sushmitha \\ Department of Horticulture and Postharvest Technology, Institute of Agriculture, \\ Visva-Bharati, Sriniketan-731236, West Bengal, India \\ *Corresponding author
}

\section{A B S T R A C T}

\begin{tabular}{l} 
Key w o r d s \\
Papaya, Seed \\
treatment, \\
$\begin{array}{l}\text { Germination and } \\
\text { seedling growth }\end{array}$ \\
\hline Article Info \\
$\begin{array}{l}\text { Accepted: } \\
10 \text { March } 2020 \\
\text { Available Online: } \\
10 \text { April } 2020\end{array}$ \\
\hline
\end{tabular}

Being a tropical delicious fruit papaya is favored due to its yellowish orange colored soft sweet ripe pulp as well as green fruit as culinary purpose. The plant is commonly propagated by seeds and the seed germination is greatly affected by seed treatment to overcome barrier of germination from sarcotesta as well as the inhibitors present beneath the seed coat. In the present experiment seeds of Ranchi variety were soaked for 24 hours in the solutions of coconut water @ 50\%, tomato juice @ $20 \%$, cow urine @ 20\%, $\mathrm{GA}_{3} @ 200 \mathrm{ppm}, \mathrm{NAA} @ 200 \mathrm{ppm}, \mathrm{KNO}_{3} @ 0.5 \%$ and normal water (control) and sown in polythene bags. Maximum seed germination was obtained under $\mathrm{GA}_{3} @$ 200ppm. Higher rate of seed germination was also observed in the seeds treated with $50 \%$ coconut water and NAA@ 200 ppm. Speed of germination was recorded highest in the seeds treated with $\mathrm{GA}_{3} @$ 200ppm. However, seedling growth with respect to plant height, and root length, and leaf area, chlorophyll content in leaf was receded maximum under treatment with NAA @ 200 ppm. Germination was inhibited by $\mathrm{KNO}_{3}$ and tomato juice treatment where rate of seed germination was observed lower than the control. Seeds were treated with same treatments and tested under laboratory condition and the results supported the result of the experiment conducted under field condition. Thus it can be concluded that for better germination of papaya seeds the seed treatment with $\mathrm{GA}_{3} @ 200 \mathrm{ppm}$. Seed treatment with coconut water (50\%) can also improve seed germination of papaya significantly. However, with respect to seedling growth application of NAA @ 200 ppm or cow urine @ $20 \%$ as seed treatment was best. Overall, NAA @ 200 ppm was best as seed treatment of papaya.

\section{Introduction}

Papaya (Carica papaya L.) is a delicious tropical fruit, known as wonder fruit of the tropics, it belongs to family Caricaceae. It was introduced to India by Portuguese in 1611. Being a tropical fruit papaya also grown in sub-tropical regions of the country up to $1,000 \mathrm{~m}$ above sea level. Papaya is a remunerative fruit crop, gives maximum yield per unit area and income next to banana. It is also grown in kitchen garden, home garden or nutrition garden for fruit as well as vegetable.

Papaya it is very nutrition's with respect to vitamins. It value crops in is the 2 nd rich vitamin-A (2020IU) after mango crops. It also contains vitamin-B B $_{2}(250 \mathrm{mg} / 100 \mathrm{gm})$. Papaya Yellow color in papaya (the vitamin A) is associated with $\beta$ carotene but the yellow 
pigment of papaya is caricaxanthene $\left(\mathrm{C}_{40} \mathrm{H}_{56} \mathrm{O}\right)$. It is used a digestive aid and for the treatment of ulcer $\&$ diphtheria. It is used as clarifying agent for beer, pre-shrinking of wool and degumming of natural silk and rayon. Papaya used in the preparation of drugs for treatment of intestinal cancer, tapeworms, and kidney disorders. The milky latex which is obtained from immature fruits is known as papain, a proteolytic enzyme used in several ways (Tenderization of meat and it is used for tanning of leathers etc).

Apart from papain, raw fruits can also be used for extraction of pectin. Papaya is usually propagated through seed. Seed germination is effected by many factors, which include the type of substrate used etc, environmental factors such as temperature, oxygen, water. Germination inhibitors also makes slow or prevent seed germination. Sarcotesta also lowers germination and result in erratic and incomplete germination. Pretreatment of seeds has significant impact on breaking dormancy, enhancing seed germination and growth development of seedling (Deb et al., 2010; Pandit et al., 2013 and Padma et al., 2001).

$\mathrm{GA}_{3}$ is reported to be very effective in increasing seed germination and seedling growth additionally benzyl adenine, naphthalene acetic acid, sodium thiosulphate, potassium nitrate, thiourea are also in used for the same (Choudhary et al., 2018).As the quality seedling is the major criteria for successful cultivation of papaya, seed germination followed by seedling growth is most important in nursery management of papaya.

Different growth regulators such as gibberellic acid and naphthalene acetic acid etc. are used to improve seed germination (Anburani and Shakila, 2010). Moreover, different inorganic salts $\left(\mathrm{KNO}_{3}\right.$, Borax,
$\left.\mathrm{ZnSO}_{4}\right)$ etc. are generally used to increase seed germination and seedling growth of papaya.

\section{Materials and Methods}

The field experiment was conducted at the Horticultural Form, Department of Horticulture and Post-Harvest Technology, Palli Sikaha Bhavana, Visva-Bharati, Sriniketan from September 2018 to January 2019. The experiment was laid out in Completed Randomized Design (CRD) with 7 treatment and 3 replications 100 seed were sown in poly bags $(12 \mathrm{~cm} x 10 \mathrm{~cm})$ media comprising garden soil, sand, FYM and vermi-compost @ 2:2:1:1 (Abirami et al., 2010), and under laboratory condition Seed treatment with different materials are mention below viz. $\left(\mathrm{T}_{1}\right.$ Coconut water @ 50\%, $\mathrm{T}_{2} \mathrm{GA}_{3}$ @ 200ppm, T 3 NAA @ 200 ppm, T 4 Cow urine @ 20\%, $\mathrm{T}_{5}$ Tomato juice @ 20\%, $\mathrm{T}_{6}$ $\mathrm{KNO}_{3} @ 0.5 \%$ and $\mathrm{T}_{7}$ Control including untreated), replicated thrice, seeds were soaked for 24 hours with various concentrations of chemicals and organic supplement.

Seeds were sown at $1 \mathrm{~cm}$ depth in the black poly bag of filled with prepared growing medium (one seed per poly bags) and seeds were soaked in the respective solution for 24 hours, washed and then placed in petri plates with moist filter paper in under laboratory condition. All the poly bags were then kept under poly tunnel. Light irrigation was given with rosecan after sowing.

The poly bags were lightly watered daily with rose can up to germination. Regular watering, weeding and application of pesticide and fungicides hare been carried out to get healthy seedlings. The observations on the parameters listed below were recorded daily for germination parameters and after 45 days for growth parameters. 


\section{Results and Discussion}

\section{Germination attributes}

In the present study the observations (Table 1 and 2) of different parameters under different seed treatment showed the significant effect on papaya seed germination. Germination percentage was found significantly maximum $(75 \%)$ in $\mathrm{T}_{2}\left(\mathrm{GA}_{3} @ 200 \mathrm{ppm}\right)$ and minimum (5.0\%) was recorded in $\mathrm{T}_{6}\left(\mathrm{KNO}_{3}\right.$ (@ 0.5\%). Speed of germination found maximum (2.07) in $\mathrm{T}_{2}\left(\mathrm{GA}_{3} @ 200\right)$ ppm followed by $\mathrm{T}_{1}(1.74)$ and minimum was found in $\mathrm{T}_{6} \mathrm{KNO}_{3}(0.22)$. Barche et al., (2010) identified response of seed treatment on gibberellic acid at @ 500 ppm of different cultivars of papaya and found that the maximum germination. In perti plate are germination percentage was maximum $(77 \%)$ in $\mathrm{T}_{2}\left(\mathrm{GA}_{3} @ 200 \mathrm{ppm}\right)$ and minimum $(18.52 \%)$ in $\mathrm{T}_{5}$ (Tomato juice @ 20\%). Speed of germination has been recorded highest (3.35) in $\mathrm{T}_{2}\left(\mathrm{GA}_{3} @ 200\right.$ ppm) and least (0.50) was observed in $\mathrm{T}_{5}$ (Tomato juice @ 20\%) and it was lower (2.50) than the control $\left(\mathrm{T}_{7}\right)$.

\section{Seedling growth parameters}

Analysis of observation as presented in table number 1 and 2 exhibited that the Seed treatment is different growth regulators, chemicals and organic supplements on papaya in observation of height of seedling (cm),number of leaves per seedling, stem diameter $(\mathrm{mm})$, leaf area $(\mathrm{cm})$, fresh weight of shoot $(\mathrm{g})$, fresh weight of root $(\mathrm{g})$, dry weight of shoot $(\mathrm{g})$ and dry weight of root $(\mathrm{g})$, root length $(\mathrm{cm})$, root diameter $(\mathrm{mm})$ and chlorophyll content in leaf of papaya are recorded to 45 DAS.

The maximum height of the seedlings $(15.37 \mathrm{~cm})$ was recorded in $\mathrm{T}_{3}$ (NAA @ $200 \mathrm{ppm})$ and minimum $(3.54 \mathrm{~cm})$ in $\mathrm{T}_{5}$ (Tomato juice@ 20\%). Lay et al., (2015) reported best germination of papaya seeds by breaking dormancy of cultivar Surya with $\mathrm{GA}_{3} @ 300$ ppm for $12 \mathrm{~h}$ and $\mathrm{KNO}_{3} @ 2 \%$ for $24 \mathrm{~h}$. In the present experiment number of leaves of papaya seedlings was highest (10.50) in $\mathrm{T}_{4}$ (Cow urine @ 20\%) while lowest number of leaves (4.11) was noted in $\mathrm{T}_{5}$ (Tomato juice@20\%). This finding has the conformity with the findings of Meena and Jain (2012).

Stem diameter of seedlings has been recorded maximum $\left(3.60 \mathrm{~mm}\right.$ ) in treatment $\mathrm{T}_{4}$ (Cow urine @ 20\%) followed by $\mathrm{T}_{2}\left(\mathrm{GA}_{3} @\right.$ 200ppm) (3.06 mm). Lowest stem diameter (1.03 mm) was found in $\mathrm{T}_{5}$ (Tomato juice @ $20 \%)$. Maximum leaf area $\left(86.26 \mathrm{~cm}^{2}\right)$ was observed in $\mathrm{T}_{3}$ (NAA @ 200ppm). However, significantly lowest leaf area $\left(19.37 \mathrm{~cm}^{2}\right)$ was observed in $\mathrm{T}_{6}\left(\mathrm{KNO}_{3} @ 0.5 \%\right)$. Maximum fresh weight shoot obtained in $(9.30 \mathrm{~g})$ in $\mathrm{T}_{3}$ (NAA @ 200 ppm). Whereas, minimum weight are $(0.84 \mathrm{~g})$ in $\mathrm{T}_{5}$ (Tomato juice @ 20\%). Choudhary et al., (2018) and Kumawat et al., (2014) also reported the similar results.

Fresh weight of root was maximum $(1.46 \mathrm{~g})$ in $\mathrm{T}_{3}$ (NAA @ 200 ppm) and $\mathrm{T}_{4}$ (Cow urine @ 20\%). Minimum fresh root weight $(0.19 \mathrm{~g})$ was obtained in $\mathrm{T}_{6}\left(\mathrm{KNO}_{3} @ 0.5 \%\right)$. Dry weight of shoot was maximum in $(1.74 \mathrm{~g})$ at $\mathrm{T}_{3}$ (NAA @ 200 ppm) and minimum (0.04 g.) in $\mathrm{T}_{7}$ (Control) at 45 DAS. Dry weight of root has been observed maximum $(0.42 \mathrm{~g})$ in $\mathrm{T}_{4}$ (Cow urine@20\%).

Lowest dry weight of root $(0.006 \mathrm{~g})$ was obtained in $\mathrm{T}_{5}$ (Tomato juice @ 20\%). Root length was highest $(31.63 \mathrm{~cm})$ reordering $\mathrm{T}_{2}$ $\left(\mathrm{GA}_{3} @ 200\right.$ ppm). However, lowest root length $(8.64 \mathrm{~cm})$ was noted in $\mathrm{T}_{6}\left(\mathrm{KNO}_{3} @\right.$ $0.5 \%)$. Maximum root diameter $(7.47 \mathrm{~mm})$ has been observed in $\mathrm{T}_{4}$ (Cow urine @ 20\%) closely followed by $\mathrm{T}_{3}$ (NAA @ 200 ppm) $(7.24 \mathrm{~mm})$. The findings of the present study have conformity with the findings of Anburani and Shakila (2010) and Deb et al., (2010). 
Table.1 Effect of seed pre-treatments on seed germination and seedling growth of papaya under field condition

\begin{tabular}{|c|c|c|c|c|c|c|c|c|c|c|c|c|c|}
\hline Treatments & $\begin{array}{c}\text { Germination } \\
\text { percentage } \\
(\%)\end{array}$ & $\begin{array}{c}\text { Speed of } \\
\text { germination }\end{array}$ & $\begin{array}{l}\text { Height of } \\
\text { seedling } \\
(\mathrm{cm})\end{array}$ & $\begin{array}{l}\text { Number of } \\
\text { leaves per } \\
\text { seedling }\end{array}$ & $\begin{array}{c}\text { Stem } \\
\text { diameter } \\
(\mathbf{m m})\end{array}$ & $\begin{array}{l}\text { Leaf } \\
\text { area } \\
(\mathrm{cm})\end{array}$ & $\begin{array}{c}\text { Fresh } \\
\text { weight of } \\
\text { shoot }(g)\end{array}$ & $\begin{array}{c}\text { Fresh } \\
\text { weight of } \\
\text { root }(\mathrm{g})\end{array}$ & \begin{tabular}{l}
\multicolumn{1}{c}{ Dry } \\
weight of \\
shoot $(g)$
\end{tabular} & $\begin{array}{l}\text { Dry weight } \\
\text { of root (g) }\end{array}$ & $\begin{array}{c}\text { Root } \\
\text { length } \\
(\mathrm{cm})\end{array}$ & $\begin{array}{l}\text { Root } \\
\text { diameter } \\
(\mathbf{m m})\end{array}$ & $\begin{array}{l}\text { Chlorophyll } \\
\text { content in } \\
\text { leaf (SPAD) }\end{array}$ \\
\hline $\begin{array}{l}T_{1} \text { (Coconut water } \\
\text { @ 50\%) }\end{array}$ & 65.83 & 1.74 & 14.67 & 9.40 & 2.59 & 83.46 & 6.80 & 1.20 & 1.41 & 0.21 & 27.00 & 6.51 & 50.23 \\
\hline $\begin{array}{l}T_{2} \text { (Gibberellic } \\
\text { acids @200ppm) }\end{array}$ & 75.00 & 2.07 & 14.81 & 10.30 & 3.06 & 63.03 & 7.76 & 0.93 & 0.73 & 0.04 & 31.63 & 6.23 & 40.73 \\
\hline $\begin{array}{l}T_{3}(\text { Napthalmic } \\
\text { acetic acid @ } 200 \\
\text { ppm) }\end{array}$ & 63.33 & 1.63 & 15.37 & 9.66 & 2.54 & 86.26 & 9.30 & 1.46 & 1.74 & 0.25 & 26.16 & 7.24 & 65.15 \\
\hline $\begin{array}{l}\mathbf{T}_{4}(\text { Cow urine @ } \\
20 \%)\end{array}$ & 58.33 & 1.50 & 13.80 & 10.50 & 3.60 & 71.63 & 8.03 & 1.46 & 1.05 & 0.42 & 21.87 & 7.47 & 62.38 \\
\hline $\begin{array}{l}\mathbf{T}_{5} \text { (Tomato juice } \\
\text { @ 20\%) }\end{array}$ & 5.50 & 0.47 & 3.54 & 4.11 & 1.03 & 28.55 & 0.86 & 0.20 & 0.14 & 0.006 & 10.30 & 1.96 & 20.99 \\
\hline $\begin{array}{l}\mathrm{T}_{6}\left(\mathrm{KNO}_{3}\right. \\
\text { Potassium nitrate } \\
\text { @ } 0.5 \%)\end{array}$ & 5.00 & 0.22 & 5.16 & 4.32 & 1.11 & 19.37 & 0.84 & 0.19 & 0.05 & 0.018 & 8.64 & 1.96 & 23.30 \\
\hline $\begin{array}{l}\mathbf{T}_{7}(\text { Control } \\
\text { Distilled water })\end{array}$ & 17.50 & 0.41 & 5.65 & 5.06 & 1.57 & 31.94 & 1.66 & 0.26 & 0.04 & 0.021 & 17.66 & 2.80 & 28.72 \\
\hline $\mathrm{SE} \pm(\mathrm{m})$ & 1.40 & 0.04 & 0.18 & 0.23 & 0.09 & 1.85 & 0.22 & 0.02 & 0.04 & 0.01 & 0.80 & 0.12 & 1.15 \\
\hline C.D. $(5 \%)$ & 4.22 & 0.13 & 0.57 & 0.69 & 0.38 & 5.57 & 0.67 & 0.07 & 0.12 & 0.03 & 2.42 & 0.37 & 3.45 \\
\hline
\end{tabular}

Table.2 Effect of seed pre-treatments on seed germination and seedling growth of papaya under laboratory condition

\begin{tabular}{|c|c|c|c|c|c|}
\hline Treatments & $\begin{array}{c}\text { Germination } \\
\text { percentage }(\%)\end{array}$ & $\begin{array}{c}\text { Speed of } \\
\text { germination }\end{array}$ & Root length (cm) & $\begin{array}{l}\text { Length of Seedling } \\
\text { in }(\mathrm{cm})\end{array}$ & Shoot length (cm) \\
\hline $\mathrm{T}_{1}$ (Coconut water @ 50\%) & 70.40 & 2.5 & 2.8 & 9.0 & 6.5 \\
\hline$T_{2}$ (Gibberellic acids @200ppm) & 77.03 & 3.3 & 3.3 & 9.4 & 6.03 \\
\hline $\mathrm{T}_{3}$ (Napthalmic acetic acid @ 200 ppm) & 65.5 & 2.4 & 2.4 & 3.3 & 1.29 \\
\hline $\mathbf{T}_{4}($ Cow urine @ 20\%) & 70.4 & 1.9 & 1.9 & 4.4 & 2.5 \\
\hline $\mathrm{T}_{5}$ (Tomato juice @ 20\%) & 18.5 & 0.5 & 0.5 & 3.6 & 3.1 \\
\hline $\mathrm{T}_{6}\left(\mathrm{KNO}_{3}\right.$ Potassium nitrate @ $\left.0.5 \%\right)$ & 22.6 & 1.2 & 1.2 & 4.4 & 3.1 \\
\hline $\mathbf{T}_{7}($ Control Distilled water $)$ & 40.9 & 2.5 & 2.0 & 6 & 3.3 \\
\hline $\mathrm{SE} \pm(\mathrm{m})$ & 1.52 & 0.07 & 0.12 & 0.30 & 0.07 \\
\hline C.D. $(5 \%)$ & 4.57 & 0.21 & 0.38 & 0.90 & 0.21 \\
\hline
\end{tabular}


However, minimum root diameter $(1.96 \mathrm{~mm})$ was noted in $\mathrm{T}_{5}$ (Tomato juice @ 20\%). Leaf chlorophyll content of papaya seedlings at 45 DAS was recorded highest (65.15 SPAD) in $\mathrm{T}_{3}$ (NAA @ 200 ppm) which was closely followed by $\mathrm{T}_{4}$ (Cow urine @ 20\%) (62.38 SPAD). However, the minimum chlorophyll content (20.99 SPAD) was recorded in $\mathrm{T}_{5}$ (Tomato juice@20\%).

From the findings of the present investigation it is clear that among all the treatments of growth regulators, chemicals and organic supplements maximum seed germination and speedy germination was obtained under $\mathrm{GA}_{3}$ @ 200 ppm. Higher rate of seed germination was also observed in the seeds treated with $50 \%$ Coconut water and NAA @ 200 ppm. However, seedling growth with respect to plant height, chlorophyll content, leaf area, fresh weight shoot and root, dry weight shoot and root girth was receded maximum under treatment with NAA @ 200 ppm followed by cow urine $(20 \%)$.Germination was inhibited by $\mathrm{KNO}_{3}$ and tomato juice treatment where rate of seed germination was observed lower than the control.

Thus it can be concluded that for better germination of papaya seeds the seed treatment with $\mathrm{GA}_{3} @ 200 \mathrm{ppm}$ both in laboratory as well as field. Seed treatment with coconut water $(50 \%)$ can also improve seed germination of papaya significantly. However, with respect to seedling growth application of NAA @ 200 ppm or cow urine @ $20 \%$ as seed treatment was best. Overall, NAA@200 ppm was best as seed treatment of papaya.

\section{References}

Abirami, A., Reema, J., Mathew, P. A., Srinivasan, V. and Hamza, S. 2010. Effect of different propagation media on seed germination, seedling growth and vigour of nutmeg (Myristica fragrans Houtt.). J. Medicinal Plants Res., 4(19): 2054-2058.

Anburani, A. and Shakila, A. 2010. Influence of seed treatment on the enhancement of germination and seedling vigour of papaya. Acta Hort., 851: 295-298.

Barche, S., Kirad, K. S. and Singh, D. B. 2010. Response of seed treatment on germination, growth, survivability and economics of different cultivars of papaya (Carica papaya L.). Acta Hort., 851: 279-284.

Choudhary, R. C., Kanwar, J., Chouhan, G. S., Sing, P., and Tanwar, D. R. 2018. Effect of $\mathrm{GA}_{3}$ and growing media on seedling growth of papaya (Carica papaya L.) cv. Pusa Nanha. Inter. J. of Che. Stud., 6(6): 1008-1012.

Deb, P., Das, A., Ghosh, S. K. and Suresh, C. P. 2010. Improvement of seed germination and seedling growth of papaya (Carica papaya L.) through different pre-sowing seed treatments. Acta Hort., 581:313-316.

Kumawat, R., Maji, S., Govind and Meena, D. C. 2014. Studies on seed germination and seedling growth of papaya (Carica papaya L.) cv. Coorg Honey Dew as influenced by media and chemicals. $J$. Crop and Weed, 10(2): 281-286.

Lay, P., Basvaraju, G. V., Pashte, V. V., and Gowri, M. 2015. Studies on effect of giberellic acid $(\mathrm{Ga} 3)$ and potassium nitrate $\left(\mathrm{KNO}_{3}\right)$ on breaking of seed dormancy of papaya (Carica papaya L.) Cv. Surya. An Int. Quarterly Env.l Sci., 9(1\&2): 111-115.

Meena, R. R. and Jain, M. C. 2012. Effect of seed treatment with gibberellic acid on growth parameters of papaya seedlings (Carica papaya L.). Progressive Hort., 44(2):248-250.

Padma Lay., Basavaraju, G. V., Sarika, G. and Amrutha, N. 2013. Effect of seed treatments to enhance seed quality of 
papaya (Carica papaya L.) cv. Surya. Glo. J. Bio., Agri. and Health Sci., 2(3): 221-225.

Pandit, V. K., Shantha Nagaraja and Sinha J. P. 2001. Improving papaya (Carica papaya) seed gammadion and seedling growth by pre-sowing treatments. Ind.
J. Agri. Sci., 71 (11): 704-6.

Ravishankar Chauhan, S.K. Jadhav and Afaque Quraishi 2014. An Efficient Seed Germination and Seedling Establishment Protocol for Hybrid (Carica papaya Linn). Sci. alert, 139.142.

\section{How to cite this article:}

Gangaram Rana, Prahlad Deb, Buddhisatya Dowarah and Kanne Sushmitha. 2020. Effect of Seed pre treatment on Seed Germination and Seedling Growth of Papaya. Int.J.Curr.Microbiol.App.Sci. 9(04): 1066-1071. doi: https://doi.org/10.20546/ijcmas.2020.904.126 